\title{
Implications of taxonomic modifications and alien species on biological water quality assessment as exemplified by the Belgian Biotic Index method
}

\author{
W. Gabriels*, P. L. M. Goethals \& N. De Pauw \\ Laboratory of Environmental Toxicology and Aquatic Ecology, Ghent University, J. Plateaustraat 22, 9000 Ghent, Belgium \\ (*Author for correspondence: E-mail: w.gabriels@vmm.be)
}

Key words: biological assessment methods, macroinvertebrates, surface water, exotic species

\begin{abstract}
In this paper, some important problems related to taxonomic resolution in water quality assessment by means of macroinvertebrates are discussed. Most quality indices based on macroinvertebrates only require identification up to genus or family level. Although this can be seen as a practical trade-off between taxonomic precision and time constraints and financial resources, it can result in biased assessment scores for certain stream types. An additional difficulty of identification levels other than species is caused by possible changes in taxonomy over time. A given genus may indeed have been split up into two or more genera or a species could be assigned to a different genus. These changes may alter biotic index values calculated over time, due to a change in number of taxa or replacement of one taxon by another one having a different tolerance class. An additional problem is caused by the invasion of exotic species. The genus Corbicula for instance is currently invading Belgian watercourses in increasing numbers. Since no Belgian Biotic Index (BBI) tolerance class is defined for Corbicula, this may cause inconsistencies in index calculations as well. In order to eliminate these, a semi-fixed taxa list, including a tolerance class for each taxon, for BBI calculation is proposed.
\end{abstract}

\section{Introduction}

In biomonitoring, two approaches can be distinguished: the bioconservation approach, where biodiversity and species conservation are the key incentives for sampling an aquatic habitat, and the bioassessment approach, where the focus is on water quality assessment and hence, insight in the biological community is a means rather than a goal. The former approach implies a species-level identification of the sampled organisms, while the latter usually involves a trade-off between a higher level of identification with lower costs but a less precise outcome, and a species-level identification with higher costs but a higher precision. The objectives of a sampling campaign should there- fore be decisive for the choice of identification level. In this paper, some problems related to taxonomic resolution in water quality assessment by means of macroinvertebrates are discussed.

Various authors recommend identification to species level to ascertain a detailed insight in the community composition, avoiding information loss due to lumping of taxa, and showing a strong assemblage-environment relationship (e.g. Resh \& McElravy, 1993; Stubauer \& Moog, 2000; Verdonschot, 2000; Lenat \& Resh, 2001; King \& Richardson, 2002; Adriaenssens et al., 2004). On the other hand, species identification is time-consuming and expensive. On top of that, information loss when identifying to genus or even family level is often small, and according to several authors it 
is therefore not necessary to descend to the species level (e.g. Warwick, 1988; Bowman \& Bailey, 1997; Ghetti, 1997; Olsgard et al., 1998; Dolédec et al., 2000; Gayraud et al., 2003). Another problem associated with species level identifications is the increasing uncertainty that arises with an increasing level of detail. Ellis (1985) acknowledged this when defining taxonomic sufficiency as the level to which the organisms should be identified in order to balance the need to indicate the biological community versus accuracy of the identifications. When deciding upon the taxonomic level, all aspects mentioned above should be taken into consideration. According to Guérold (2000) and Roach et al. (2001) family level is sufficient for detecting perturbations on the macroinvertebrate community, but a more detailed level of identification is necessary for ecological interpretation. Williams \& Gaston (1994) proposed the use of higher-taxon categories as surrogates for species in rapid biodiversity surveys. Karr \& Chu (1999) consider genus level to be sufficient for developing a multimetric index and also family level to be acceptable in case of limited time and/or financial resources.

Whatever taxonomic level is used for a biotic water quality index, the level should be fixed with the method description because (1) many methods can only be calculated when using the predefined level, e.g. when taxon-specific tolerance values are defined and (2) taxonomic level can affect index calculation (e.g. Guérold, 2000; Schmidt-Kloiber \& Nijboer, 2004).

An additional difficulty with identification levels other than species, however, is caused by possible changes in taxonomy over time, giving rise to inconsistencies in index calculation. A given genus may be split up into two or more genera or a species can be assigned to a different genus. These changes may alter the value of the biotic indices calculated based on the given taxa, respectively because the number of taxa (of a level higher than species) has changed or a taxon is replaced by another one (having a different tolerance class). This is demonstrated by a simple example of Belgian Biotic Index (BBI) calculation of a virtual sample.

Similar problems are due to the invasion of exotic species. Newly occurring taxa raise discussions whether or not to include them in the existing index, which may imply defining a tolerance class for the new taxon, as used in most biotic index methods. This problem has risen for at least one exotic genus in Belgium, as will be discussed later.

\section{Calculation of the BBI}

The BBI method is a standardised method to assess biological quality of watercourses based on the macroinvertebrate community. The method was proposed by De Pauw \& Vanhooren (1983) and has been adopted as a standard method by the Belgian Institute of Normalisation (IBN, 1984). Since its first publication, the method has been extensively used to assess water quality in Belgium but also abroad (De Pauw \& Hawkes, 1993). Since 1989, the Flemish Environment Agency (VMM) assesses around thousand sites throughout Flanders (Belgium) each year by means of the BBI.

The BBI combines characteristics of the indices proposed by Woodiwiss in the UK (1964, Trent Biotic Index) and Tuffery and Verneaux in France (1968, Indice Biotique). The method is based on aquatic macroinvertebrates sampled with a standard handnet, as in the method of Woodiwiss (1964) and the calculation of the biotic index using the table as proposed by Tuffery \& Verneaux (1968). Some adaptations were made concerning the sampling method and the taxonomic level of identification. Table 1 summarises the taxonomic levels of identification for the BBI as proposed by De Pauw \& Vanhooren (1983). Only taxa of which at least two individuals are found in the sample, are taken into account. The calculation of the BBI is based on a combination of the highest tolerance class encountered, the class frequency within the highest tolerance class and the total number of taxa (Table 2). For instance, a sample containing 9 taxa, 2 of which having a tolerance class of 3 (being the lowest tolerance class encountered in the sample) would be assigned a BBI of 5. The column with indicator groups in Table 2 contains some modifications, which will be discussed further in this paper. BBI values correspond to water quality classes with their associated formal valuation, which are summarised in Table 3 (De Pauw \& Vanhooren, 1983).

Bervoets et al. (1989) proposed, along with some modifications in sample processing, to 
Table 1. Identification levels of macroinvertebrate taxa for calculating the BBI (De Pauw \& Vanhooren, 1983)

\begin{tabular}{ll}
\hline Taxonomic group & Determination level of systematic units \\
\hline Plathelminthes & Genus \\
Oligochaeta & Family \\
Hirudinea & Genus \\
Mollusca & Genus \\
Crustacea & Family \\
Plecoptera & Genus \\
Ephemeroptera & Genus \\
Trichoptera & Family \\
Odonata & Genus \\
Megaloptera & Genus \\
Hemiptera & Genus \\
Coleoptera & Family \\
Diptera & Family, excl. Chironomidae \\
& (Chironomidae thummi-plumosus, \\
Hydracarina & Chironomidae non-thummi-plumosus $)$ \\
\hline
\end{tabular}

include taxa represented by only one individual in BBI calculation, but this modification was never incorporated into routinely monitoring schemes of the VMM.
Table 3. Water quality classes corresponding to the BBI values (De Pauw \& Vanhooren, 1983)

\begin{tabular}{|c|c|c|c|}
\hline Quality class & BBI & Colour code & Valuation \\
\hline I & $9-10$ & Blue & $\begin{array}{l}\text { Lightly polluted or } \\
\text { unpolluted }\end{array}$ \\
\hline II & $7-8$ & Green & Slightly polluted \\
\hline III & $5-6$ & Yellow & Moderately polluted \\
\hline IV & $3-4$ & Orange & Heavily polluted \\
\hline $\mathrm{V}$ & $0-2$ & Red & Very heavily polluted \\
\hline
\end{tabular}

\section{Inconsistencies due to taxonomic modifications}

De Pauw \& Vannevel (1991) published keys in Dutch for identification of aquatic macroinvertebrates, for each group up to the appropriate BBI level. Since the publication of these identification keys, taxonomy of some groups of macroinvertebrates was changed, resulting in genera splitting up into more than one genus. Examples are the gastropod genera Lymnaea, Stagnicola, Radix and Galba, formerly all considered as Lymnaea species; the gastropod Physella, formerly belonging to the genus Physa; and Aquarius najas (De Geer, 1773), formerly belonging to the genus Gerris. As a result,

Table 2. Calculation of the BBI, based on the highest tolerance class encountered, the class frequency within the highest tolerance class and the total number of taxa (De Pauw \& Vanhooren, 1983)

\begin{tabular}{|c|c|c|c|c|c|c|}
\hline \multirow{2}{*}{$\begin{array}{l}\text { Tolerance class } \\
\text { Indicator groups }\end{array}$} & \multirow{2}{*}{$\begin{array}{l}\text { Class } \\
\text { Frequency }\end{array}$} & \multicolumn{5}{|c|}{ Number of taxa } \\
\hline & & $0-1$ & $2-5$ & $6-10$ & $11-15$ & $\geq 16$ \\
\hline \multirow[t]{2}{*}{ 1. Plecoptera; Heptageniidae } & $\geq 2$ & - & 7 & 8 & 9 & 10 \\
\hline & 1 & 5 & 6 & 7 & 8 & 9 \\
\hline \multirow[t]{2}{*}{ 2. Cased Trichoptera } & $\geq 2$ & - & 6 & 7 & 8 & 9 \\
\hline & 1 & 5 & 5 & 6 & 7 & 8 \\
\hline \multirow{2}{*}{$\begin{array}{l}\text { 3. Ancylidae; Acroloxus; Ephemeroptera } \\
\text { (excl. Heptageniidae) }\end{array}$} & $>2$ & - & 5 & 6 & 7 & 8 \\
\hline & $1-2$ & 3 & 4 & 5 & 6 & 7 \\
\hline $\begin{array}{l}\text { 4. Aphelocheirus; Odonata; Gammaridae; Mollusca } \\
\text { (excl. Ancylidae, Acroloxus, Sphaeriidae \& Corbicula) }\end{array}$ & $\geq 1$ & 3 & 4 & 5 & 6 & 7 \\
\hline $\begin{array}{l}\text { 5. Asellidae; Hirudinea; Sphaeriidae; Hemiptera } \\
\text { (excl. Aphelocheirus) }\end{array}$ & $\geq 1$ & 2 & 3 & 4 & 5 & - \\
\hline 6 .Tubificidae Chironomidae thummi-plumosus & $\geq 1$ & 1 & 2 & 3 & - & - \\
\hline 7. Syrphidae-Eristalinae & $\geq 1$ & 0 & 1 & 1 & - & - \\
\hline
\end{tabular}

Proposed modifications of indicator groups after Gabriels et al., this paper (in bold). 
two samples containing the same species and the same number of individuals for each species could result in a different index depending on whether the current state-of-the-art in taxonomy is followed for identifying the organisms or the taxonomic levels sensu De Pauw \& Vannevel (1991) are used.

This is demonstrated with a simple example of a BBI calculation for two virtual samples (Table 4). The two approaches produce different BBI values in both examples. Table 4 (panels A and B) gives a list of species with their respective abundances and tolerance classes. Subsequently, the BBI is calculated following both approaches. In the first example (Table 4, panel A), identification of the sample following the keys of De Pauw \& Vannevel (1991) will result in a decrease of taxa richness with two units, and a decrease of the BBI with one unit, because the genera Aquarius and Radix are assigned to other genera (Gerris and Lymnaea, respectively). In the second example (Table 4, panel B) the actual taxa richness decreases with one unit, but for BBI calculation it increases with a unit because two individuals are only counted when representing the same taxon since two is the minimal abundance for inclusion in BBI calculation. As a result, the BBI increases with two units in this case.

Both approaches can be justified since the original publication of the BBI (De Pauw \& Vanhooren, 1983) only indicates the levels of identification (Table 1). Application of the BBI sensu stricto today would therefore imply using the current levels of identification, although only using the same taxonomic identification keys at all time would lead to stable results, i.e. a time-independent calculation of BBI values.

An estimation of the percentage of actual samples for which both approaches provide different results was not possible since the identifications of the VMM are only recorded at the lumped levels (e.g. Lymnaea including Stagnicola, Radix and Galba). In order to obtain a rough indication, both approaches were compared for Anisus, a genus that was split before the publication of the identification keys of De Pauw \& Vannevel (1991) and hence all actual taxa are recorded in the VMM data set. The recorded taxa are Anisus, Armiger, Bathyomphalus, Gyraulus, Hippeutis, Planorbis and Segmentina. Two hundred and eighty four samples from the
VMM data set contained at least two individuals of at least two of the seven taxa. BBI was calculated for these samples when distinguishing the seven taxa and calculated again after summing the abundances of the seven taxa into one taxon, Anisus. For 34 samples (12.0\%), summing the taxa resulted in a BBI decrease of one unit. The other samples were not affected.

Since there is no reason to assume that taxonomic modifications will not proceed in future, this problem can only be overcome by using a fixed list of taxa at all time (or, more correctly, a semifixed list; see further). The establishment of a common list of taxa was already recommended by Woodiwiss (1980). For the German saprobic index, a fixed taxon list is already in use (DIN, 1990).

\section{Inconsistencies due to the introduction of exotic species}

Adverse effects of invasive species on ecosystems have been discussed by several authors (e.g. Lodge, 1993; Cairns \& Bidwell, 1996; Mack et al., 2000; Torchin et al., 2003). Invasion of exotic macroinvertebrate genera in Europe is increasing (e.g. Van den Brink et al., 1991; Bij de Vaate et al., 2002). These invasions cause controversy on the subject of index-based biological assessment, strongly related to the question whether or not a fixed taxa list is used. An important aspect of this controversy is the higher potential number of taxa present in monitoring samples due to these introductions, which may cause an increase in index number when using an index dependent on taxa richness. Though alpha diversity, expressed as number of taxa, may have risen, this will only be reflected in index calculation provided the new taxon is included in the list for index calculation. On the other hand, introduction of exotic species might as well cause a decrease of alpha diversity, which is masked due to a higher taxonomic identification level. For example, the invader Dikerogammarus villosus (Sowinsky, 1894) (Crustacea, Gammaridae) might outcompete a number of native gammarid species (e.g. Bij de Vaate et al., 2002), but this will not influence the results of the index calculation at family level of a given sample since Gammaridae are still present. 


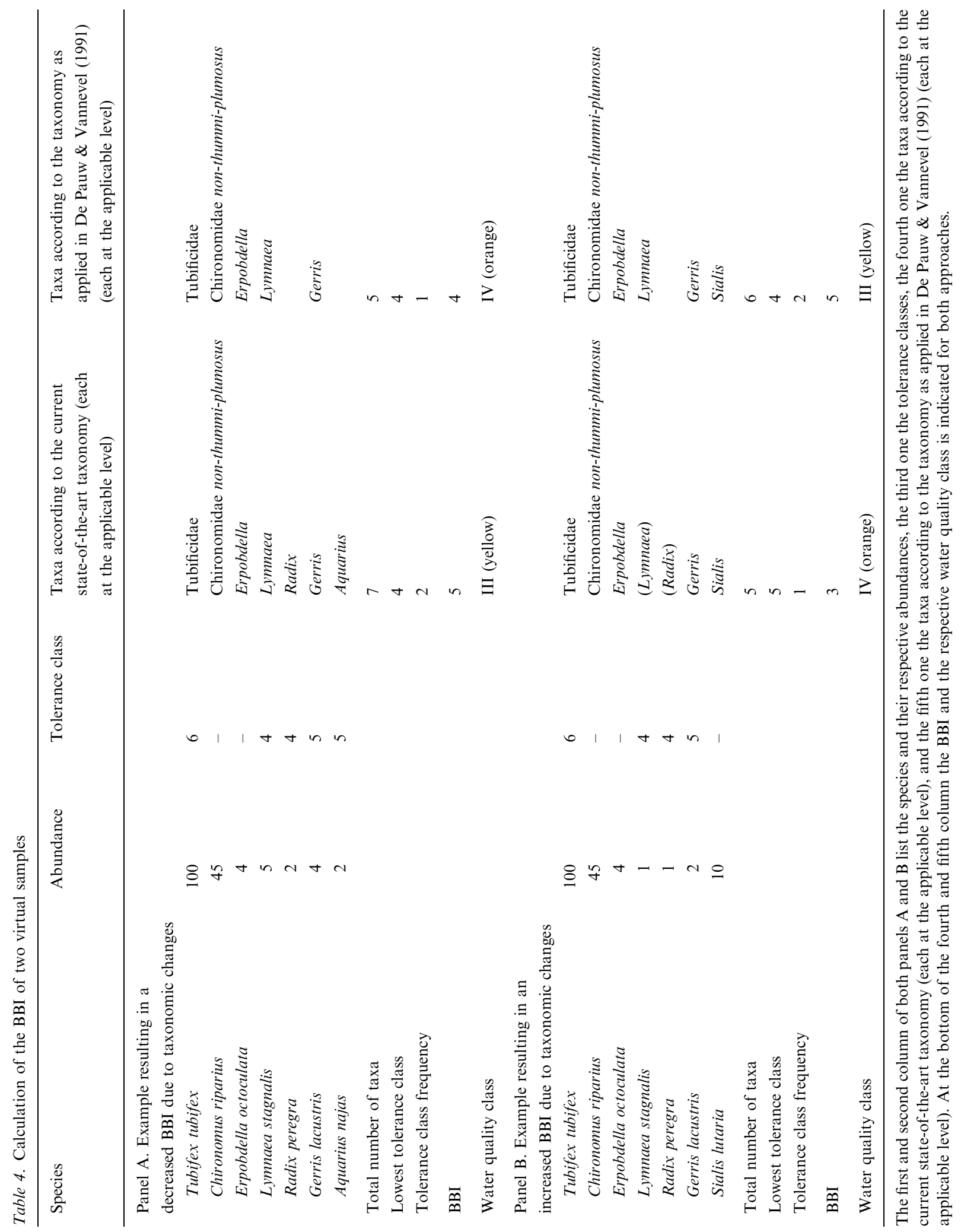


Nguyen \& De Pauw (2002) reported the invasion of the Asian clams Corbicula fluminea (Müller, 1774) and Corbicula fluminalis (Müller, 1774) (Mollusca, Corbiculidae) in the Belgian section of the river Meuse, and some of the connected canals in the early 1990s and the continuing colonisation of Corbicula species in Belgian watercourses. They could not establish a correlation between the clam density or proportion and the quality of the sediment. Since no tolerance class is defined for Corbicula, this may cause inconsistencies in BBI calculations due to a lack of consensus on how to deal with this phenomenon. The VMM encounters this genus more and more frequently in its biological samples. The question emerged whether or not this exotic genus should be included in BBI calculation, and if so, which tolerance class to use. A strict interpretation of the tolerance class as described by De Pauw \& Vanhooren (1983) would lead to the inclusion of Corbicula in the standard list with a tolerance class of 4 , being a non-sphaeriid mollusc, and thus being quite tolerant. By means of two calculation examples it is demonstrated that this may cause differences in index calculation (Table 5).

Table 5 (panels A and B) gives a list of taxa with their respective abundances. Then the BBI is calculated according to three different approaches. In the first approach, Corbicula is neglected, in the second it is included without tolerance class ('-') and in the third it is included with a tolerance class of 4 . Note the difference between a tolerance class '-' and the absence of a tolerance class. With a '-' tolerance the taxon is only taken into account for taxon richness, while in the absence of a tolerance class the taxon is not included at all. The first example (Table 5, panel A) is a sample actually taken by the VMM on 6 May 1998 at a sampling site in the Albert Canal at Genk. In this case, the inclusion of Corbicula leads to an increase of the BBI from 6 to 7. The VMM reported the BBI of this sampling site as 7 , and consequently this site met the basic water quality conditions $(\mathrm{BBI}=7)$ thanks to Corbicula. In the second example (Table 5, panel B), a virtual sample, it is demonstrated that the three approaches can as well lead to three different BBI values.

Eighteen samples from the data set of the VMM contained Corbicula individuals. In twelve of these samples, at least two individuals were counted and hence Corbicula was included in the BBI calculation of these samples. For one sample (Table 5, panel A), the BBI was affected when Corbicula was discarded. The number of samples was however statistically insufficient and therefore conclusions on the probability of affecting the BBI could not yet be drawn. Nguyen \& De Pauw (2002) found that including Corbicula species in the Biotic Sediment Index (BSI; De Pauw \& Heylen, 2001), altered biological sediment quality classification in $52 \%$ of the cases.

In order to obtain a more reliable indication of the frequency of BBI alteration if an alien taxon would be discarded, the same calculation was performed for Dreissena, another alien bivalve that was already included in the taxa list of De Pauw \& Vannevel (1991), with a tolerance class of 4. Dreissena is already present in Belgian waters for a longer time and consequently more data were available for comparing calculations. Four hundred and twenty one samples from the VMM data set contained at least two Dreissena individuals. The BBI was calculated for all samples and recalculated after exclusion of Dreissena. For 100 samples $(23.8 \%)$, BBI values decreased when Dreissena was excluded. Ninety eight of these $(23.3 \%)$ decreased with one BBI unit and two $(0.5 \%)$ with two units.

Biodiversity loss that is not evident at the taxonomic level of the biotic index used, is a matter of bioconservation and not of biological assessment of water quality. Therefore the new genus should be included in the taxa list since it has become part of local biodiversity. A biotic index, in casu the BBI, is partly based on a rapid biodiversity survey (expressed as number of taxa) as an indicator of the water quality, not of the ecosystem stability. Furthermore, species that invaded our regions at earlier times were already included in water quality assessment and are nowadays commonly accepted. Therefore, it is recommended to include Corbicula in the standard taxa list, despite its potential harmful effects. To obtain insight in the adverse effects of the invasion of this genus, more detailed studies - at species level - are necessary.

The VMM has already added the genus Corbicula to its standard list for calculating the BBI, however without assigning a specific tolerance class to it ('-'). In this way, Corbicula only affects the BBI through the number of taxa and not 
Table 5. Calculation of the BBI of a real (panel A) and a virtual (panel B) sample

\begin{tabular}{|c|c|c|c|c|}
\hline Taxa & Abundance & $\begin{array}{l}\text { Tolerance } \\
\text { class without } \\
\text { inclusion of } \\
\text { Corbicula }\end{array}$ & $\begin{array}{l}\text { Tolerance class if } \\
\text { Corbicula is } \\
\text { included without } \\
\text { tolerance class }\end{array}$ & $\begin{array}{l}\text { Tolerance class according to } \\
\text { De Pauw \& Vanhooren } \\
\text { (1983) sensu stricto }\end{array}$ \\
\hline \multirow{2}{*}{\multicolumn{5}{|c|}{$\begin{array}{l}\text { Panel A. Sample taken by the VMM } \\
\text { on } 6 \text { May } 1998 \text { at sampling site no. } \\
\text { VMM- } 820000 \text { in the Albert Canal at Genk }\end{array}$}} \\
\hline & & & & \\
\hline Naididae & 2 & - & - & - \\
\hline Tubificidae & 11 & 6 & 6 & 6 \\
\hline Chironomidae non-thummi-plumosus & 11 & - & - & - \\
\hline Helobdella & 1 & & & \\
\hline Erpobdella & 11 & 5 & 5 & 5 \\
\hline Gammaridae & 11 & 4 & 4 & 4 \\
\hline Atyidae & 11 & - & - & - \\
\hline Asellidae & 1 & - & - & - \\
\hline Cambaridae & 2 & - & - & - \\
\hline Bithynia & 11 & 4 & 4 & 4 \\
\hline Ancylus & 2 & 3 & 3 & 3 \\
\hline Dreissena & 11 & 4 & 4 & 4 \\
\hline Sphaerium & 11 & 5 & 5 & 5 \\
\hline Corbicula & 2 & & - & 4 \\
\hline Valvata & 2 & 4 & 4 & 4 \\
\hline Physa & 2 & 4 & 4 & 4 \\
\hline Pisidium & 2 & 5 & 5 & 5 \\
\hline Ecnomidae & 11 & - & - & - \\
\hline Total number of taxa & & 15 & 16 & 16 \\
\hline Lowest tolerance class & & 3 & 3 & 3 \\
\hline Tolerance class frequency & & 1 & 1 & 1 \\
\hline BBI & & 6 & 7 & 7 \\
\hline Water quality class & & III (yellow) & II (green) & II (green) \\
\hline \multicolumn{5}{|l|}{ Panel B. Virtual sample } \\
\hline Tubificidae & 100 & 6 & 6 & 6 \\
\hline Chironomidae thummi-plumosus & 45 & 6 & 6 & 6 \\
\hline Asellidae & 20 & 5 & 5 & 5 \\
\hline Erpobdella & 4 & 5 & 5 & 5 \\
\hline Gerris & 2 & 5 & 5 & 5 \\
\hline Corbicula & 50 & & - & 4 \\
\hline Total number of taxa & & 5 & 6 & 6 \\
\hline Lowest tolerance class & & 5 & 5 & 4 \\
\hline Tolerance class frequency & & 3 & 3 & 1 \\
\hline BBI & & 3 & 4 & 5 \\
\hline Water quality class & & IV (orange) & IV (orange) & III (yellow) \\
\hline
\end{tabular}

The first column lists the taxa, the second one the abundances, the third one the tolerance classes if Corbicula is not included, the fourth one the tolerance classes if Corbicula is included without tolerance class ('-'), and the fifth one the tolerance classes according to De Pauw \& Vanhooren (1983) sensu stricto. 
through its tolerance class, which is also the case for e.g. the taxa of Plathelminthes and most Diptera.

A number of exotic species of Ponto-Caspian origin are invading European watercourses (e.g. Bij de Vaate et al., 2002). Many of these species such as Dikerogammarus villosus, belong to a taxon (in casu Gammaridae) that is already in the list, while others will have to be included in the list as new taxa, for the same reasons as Corbicula. Some of these are very likely to be encountered in Flemish watercourses in the near future. Anticipating this, two Ponto-Caspian taxa should already be added to the list: Ampharetidae (Polychaeta) and Janiridae (Crustacea).

The presence of Hypania invalida (Grube, 1860) (Polychaeta, Ampharetidae) was recently reported in the river Meuse (Vanden Bossche et al., 2001). Although not yet encountered in VMM samples, this may be expected in the near future, especially in the Flemish stretch of the river Meuse. Therefore, Polychaeta should be added as a new group, including one taxon, Ampharetidae, with tolerance class '-', the identification level being set at family (as for Oligochaeta). Another Ponto-Caspian invader, Jaera istri (Veuille, 1979) (Crustacea, Janiridae) has also recently been encountered in the river Meuse (Usseglio-Polatera \& Beisel, 2003), although not collected in VMM samples so far. Consequently, the list of Crustacea should be extended with the family Janiridae, with tolerance class '-'.

\section{List of taxa taken into consideration}

There is indeed a growing need to ensure that the BBI-values remain comparable in future, which implies not altering the method itself, but rather clarifying the problems that emerge, to ensure its future application without being inconsistent with the past and current practice. Altering the method itself would imply making old and new applications incomparable; in other words, it would be a different index. The aim of this paper with regard to the BBI was to identify the problems that arose since 1991 and propose solutions to these problems.

Initially, a checklist by Vanhooren et al. (1982) was commonly used as a reference base for tax- onomy of the systematic levels used in the BBI calculation. Some additional taxa were added later, e.g. due to the separation of the mollusc genus Anisus into Anisus, Armiger, Bathyomphalus, Gyraulus, Hippeutis, Planorbis and Segmentina.

Although the original description of the BBI method dates from 1983, the situation in 1991 was chosen as point of reference. At that moment, the aforementioned modifications were already established and commonly accepted. The situation in 1991 was chosen as point of reference for two reasons. The first reason is that at that time a largescale monitoring network in Flanders was being initiated by the VMM, with the already cited modifications. The second reason is that the keys of the Pauw \& Vannevel (1991) are nowadays widely used and accepted as standard reference for taxonomic identification levels with regard to the BBI.

In the previous paragraphs it has been shown that taxonomic modifications and alien invasions may both lead to biased BBI calculations. Although a change of one or two units in BBI (on a $0-10$ scale) may seem insignificant, it is not. A small change in BBI may also lead to a change in the quality class (cf. Table 3). This may become (legally) crucial when this quality class boundary is also a quality standard, e.g. the boundary between the ecological quality classes 'good' and 'moderate', the target imposed by the European Water Framework Directive (EU, 2000). Moreover, a standardised assessment method should be unambiguously applicable and produce unbiased results at all times. This underpins the need for establishing a fixed taxa list. Because more exotic taxa can be expected to invade Belgian watercourses in the future, a fixed taxa list may need to be extended later with those taxa. Therefore a proposal for a fixed taxa list should be more likely called a semi-fixed list, leaving the possibility to add new taxa at a later time.

Table 6 is a proposal for a semi-fixed list to be used to calculate the BBI in order to eliminate the discussed calculation inconsistencies. This list contains 221 taxa and can be considered as a semifixed list, in the sense that the taxa already in the list cannot be altered (e.g. split up or lumped), but that the list may be extended with possible future invaders when necessary. The list is based on the taxa identification sensu De Pauw \& Vannevel (1991) with the addition of the Polychaeta family 
Table 6. Proposed semi-fixed taxa list of aquatic macroinvertebrates for calculating the BBI in order to avoid inconsistencies

\begin{tabular}{|c|c|}
\hline Taxon & Tolerance class \\
\hline \multicolumn{2}{|l|}{ Plathelmintes } \\
\hline Bdellocephala & - \\
\hline Crenobia & - \\
\hline Dendrocoelum & - \\
\hline Dugesia & - \\
\hline Phagocata & - \\
\hline Planaria & - \\
\hline Polycelis & - \\
\hline \multicolumn{2}{|l|}{ Polychaeta } \\
\hline Ampharetidae & - \\
\hline \multicolumn{2}{|l|}{ Oligochaeta } \\
\hline Aelosomatidae & - \\
\hline Branchiobdellidae & - \\
\hline Enchytraeidae & - \\
\hline Haplotaxidae & - \\
\hline Lumbricidae & - \\
\hline Lumbriculidae & - \\
\hline Naididae & - \\
\hline Tubificidae & 6 \\
\hline \multicolumn{2}{|l|}{ Hirudinea } \\
\hline Cystobranchus & 5 \\
\hline Dina & 5 \\
\hline Erpobdella & 5 \\
\hline Glossiphonia & 5 \\
\hline Haementeria & 5 \\
\hline Haemopis & 5 \\
\hline Helobdella & 5 \\
\hline Hemiclepsis & 5 \\
\hline Hirudo & 5 \\
\hline Piscicola & 5 \\
\hline Theromyzon & 5 \\
\hline Trocheta & 5 \\
\hline \multicolumn{2}{|l|}{ Mollusca } \\
\hline Acroloxus & 3 \\
\hline Ancylus & 3 \\
\hline Anisus & 4 \\
\hline Anodonta & 4 \\
\hline Aplexa & 4 \\
\hline Armiger & 4 \\
\hline Bathyomphalus & 4 \\
\hline Bithynia & 4 \\
\hline Bythinella & 4 \\
\hline Corbicula & - \\
\hline
\end{tabular}

Table 6. (Continued)

\begin{tabular}{|c|c|}
\hline Taxon & Tolerance class \\
\hline Dreissena & 4 \\
\hline Ferrissia & 3 \\
\hline Gyraulus & 4 \\
\hline Hippeutis & 4 \\
\hline Lithoglyphus & 4 \\
\hline Lymnaea s.l. & 4 \\
\hline Margaritifera & 4 \\
\hline Marstoniopsis & 4 \\
\hline Myxas & 4 \\
\hline Physa s.l. & 4 \\
\hline Pisidium & 5 \\
\hline Planorbarius & 4 \\
\hline Planorbis & 4 \\
\hline Potamopyrgus & 4 \\
\hline Pseudamnicola s.l. & 4 \\
\hline Pseudanodonta & 4 \\
\hline Segmentina & 4 \\
\hline Sphaerium & 5 \\
\hline Theodoxus & 4 \\
\hline Unio & 4 \\
\hline Valvata & 4 \\
\hline Viviparus & 4 \\
\hline \multicolumn{2}{|l|}{ Acari } \\
\hline Hydracarina s.l. & - \\
\hline \multicolumn{2}{|l|}{ Crustacea } \\
\hline Argulidae & - \\
\hline Asellidae & 5 \\
\hline Astacidae & - \\
\hline Atyidae & - \\
\hline Cambaridae & - \\
\hline Chirocephalidae & - \\
\hline Corophiidae & - \\
\hline Crangonyctidae & - \\
\hline Gammaridae & 4 \\
\hline Grapsidae & - \\
\hline Janiridae & - \\
\hline Leptestheriidae & - \\
\hline Limnadiidae & - \\
\hline Mysidae & - \\
\hline Palaemonidae & - \\
\hline Talitridae & - \\
\hline Triopsidae & - \\
\hline \multicolumn{2}{|l|}{ Ephemeroptera } \\
\hline Baetis & 3 \\
\hline
\end{tabular}


Table 6. (Continued)

\begin{tabular}{|c|c|}
\hline Taxon & Tolerance class \\
\hline Brachycercus & 3 \\
\hline Caenis & 3 \\
\hline Centroptilum & 3 \\
\hline Cloeon & 3 \\
\hline Ecdyonurus & 1 \\
\hline Epeorus & 1 \\
\hline Ephemera & 3 \\
\hline Ephemerella & 3 \\
\hline Ephoron & 3 \\
\hline Habroleptoides & 3 \\
\hline Habrophlebia & 3 \\
\hline Heptagenia & 1 \\
\hline Isonychia & 3 \\
\hline Leptophlebia & 3 \\
\hline Metreletus & 3 \\
\hline Oligoneuriella & 3 \\
\hline Paraleptophlebia & 3. \\
\hline Potamanthus & 3 \\
\hline Procloeon & 3 \\
\hline Rhitrogena & 1 \\
\hline Siphlonurus & 3 \\
\hline \multicolumn{2}{|l|}{ Odonata } \\
\hline Aeshna & 4 \\
\hline Anax & 4 \\
\hline Brachytron & 4 \\
\hline Calopteryx & 4 \\
\hline Cercion & 4 \\
\hline Ceriagrion & 4 \\
\hline Coenagrion & 4 \\
\hline Cordulegaster & 4 \\
\hline Cordulia & 4 \\
\hline Crocothemis & 4 \\
\hline Enallagma & 4 \\
\hline Epitheca & 4 \\
\hline Erythromma & 4 \\
\hline Gomphus & 4 \\
\hline Ischnura & 4 \\
\hline Lestes & 4 \\
\hline Leucorrhinia & 4 \\
\hline Libellula & 4 \\
\hline Nehalennia & 4 \\
\hline Onychogomphus & 4 \\
\hline Ophiogomphus & 4 \\
\hline Orthetrum & 4 \\
\hline Oxygastra & 4 \\
\hline Platycnemis & 4 \\
\hline
\end{tabular}

Table 6. (Continued)

\begin{tabular}{|c|c|}
\hline Taxon & Tolerance class \\
\hline Pyrrhosoma & 4 \\
\hline Somatochlora & 4 \\
\hline Sympecma & 4 \\
\hline Sympetrum & 4 \\
\hline \multicolumn{2}{|l|}{ Plecoptera } \\
\hline Amphinemura & 1 \\
\hline Brachyptera & 1 \\
\hline Capnia & 1 \\
\hline Chloroperla & 1 \\
\hline Dinocras & 1 \\
\hline Isogenus & 1 \\
\hline Isoperla & 1 \\
\hline Leuctra & 1 \\
\hline Marthamea & 1 \\
\hline Nemoura & 1 \\
\hline Nemurella & 1 \\
\hline Perla & 1 \\
\hline Perlodes & 1 \\
\hline Protonemura & 1 \\
\hline Rhabdiopteryx & 1 \\
\hline Taeniopteryx & 1 \\
\hline
\end{tabular}

\section{Hemiptera}

Aphelocheirus 4

Arctocorisa 5

Callicorixa 5

Corixa 5

Cymatia 5

Gerris s.1. 5

Glaenocorisa 5

Hebrus 5

Hesperocorixa 5

Hydrometra 5

Llyocoris $\quad 5$

Mesovelia 5

Micronecta 5

Microvelia 5

Naucoris $\quad 5$

Nepa 5

Notonecta 5

Paracorixa 5

Plea 5

Ranatra 5

Sigara 5

Velia 5


Table 6. (Continued)

\begin{tabular}{|c|c|}
\hline Taxon & Tolerance class \\
\hline \multicolumn{2}{|l|}{ Megaloptera } \\
\hline Sialis & - \\
\hline \multicolumn{2}{|l|}{ Coleoptera } \\
\hline Dryopidae & - \\
\hline Dytiscidae & - \\
\hline Elminthidae & - \\
\hline Gyrinidae & - \\
\hline Haliplidae & - \\
\hline Hydraenidae & - \\
\hline Hydrophilidae & - \\
\hline Hygrobiidae & - \\
\hline Noteridae & - \\
\hline Psephenidae & - \\
\hline Scirtidae & - \\
\hline \multicolumn{2}{|l|}{ Trichoptera } \\
\hline Beraeidae & 2 \\
\hline Brachycentridae & 2 \\
\hline Ecnomidae & - \\
\hline Glossosomatidae & 2 \\
\hline Goeridae & 2 \\
\hline Hydropsychidae & - \\
\hline Hydroptilidae & 2 \\
\hline Lepidostomatidae & 2 \\
\hline Leptoceridae & 2 \\
\hline Limnephilidae & 2 \\
\hline Molannidae & 2 \\
\hline Odontoceridae & 2 \\
\hline Philopotamidae & - \\
\hline Phryganeidae & 2 \\
\hline Polycentropodidae & - \\
\hline Psychomyidae & - \\
\hline Rhyacophilidae & - \\
\hline Sericostomatidae & 2 \\
\hline \multicolumn{2}{|l|}{ Diptera } \\
\hline Athericidae & - \\
\hline Blephariceridae & - \\
\hline Ceratopogonidae & - \\
\hline Chaoboridae & - \\
\hline \multicolumn{2}{|l|}{ Chironomidae } \\
\hline non-thummi-plumosus & - \\
\hline Chironomidae thummi-plumosus & 6 \\
\hline Culicidae & - \\
\hline Cylindrotomidae & - \\
\hline Dixidae & - \\
\hline Dolichopodidae & - \\
\hline
\end{tabular}

Table 6. (Continued)

\begin{tabular}{ll}
\hline Taxon & Tolerance class \\
\hline Empididae & - \\
Ephydridae & - \\
Limoniidae & - \\
Muscidae & - \\
Psychodidae & - \\
Ptychopteridae & - \\
Rhagionidae & - \\
Scatophagidae & - \\
Sciomyzidae & - \\
Simuliidae & - \\
Stratiomyidae & - \\
Syrphidae-Eristalinae & 7 \\
Tabanidae & - \\
Thaumaleidae & - \\
Tipulidae & - \\
\hline
\end{tabular}

The first column lists the taxa, the second one the associated tolerance classes. Lymnaea s.l. = Lymnaea or Stagnicola or Radix or Galba; Physa s.l. = Physa or Physella; Pseudamnicola s.l. = Pseudamnicola or Mercuria $;$ Hydracarina s.l. = Hydracarina or Hydrozetes; Gerris s.l. = Gerris or Aquarius.

Ampharetidae, the Mollusca genus Corbicula and the Crustacea family Janiridae. The notation 's.l.' (sensu lato) was added to those taxa that comprise one or more taxa in addition to the one actually mentioned. In the case of Hydracarina the notation s.l. already appeared on the original list of De Pauw \& Vannevel (1991) because Hydracarina s.l. comprises Hydrozetes in addition to Hydracarina s.s. (sensu stricto). Because the Belgian Insitute of Normalisation has adopted the BBI as a standard method (IBN, 1984), it is recommended that its method description (NBN T92-402) be extended by including this new semi-fixed taxa list.

Taxa belonging to groups such as Bryozoa, Hydrozoa, Nemertea, Nematoda, Ostracoda and Porifera are not included in the new taxa list. Taxa from these groups are not frequently encountered in macroinvertebrate samples. These groups already did not appear on the original list in De Pauw \& Vannevel (1991), and their addition would cause new inconsistencies between BBI calculations, since they may have been present in older samples. This problem does not arise with new, exotic taxa since they were not yet encountered in the older samples. For this reason, the mentioned groups of taxa were not added to the list. 
Comparison of the tolerance classes of Table 6 with the indicator groups from Table 2 reveals some inconsistencies as well. Acroloxus, having a tolerance class 3 , is not included in the appropriate column in Table 2. This is due to the fact that according to Vanhooren et al. (1982), Acroloxus belonged to the family Ancylidae, which is included in Table 2 among tolerance class 3. Since Acroloxus is now considered as belonging to a separate family (Acroloxidae), it should be included there as well. Furthermore, not only Sphaeriidae should be excluded from the Mollusca mentioned in tolerance class 4, but also Corbicula, Ancylidae and Acroloxus. All mentioned inconsistencies were corrected and indicated in bold in Table 2.

The proposal for future application of the BBI is therefore as follows:

(1) application of the taxa list from Table 6 with the associated tolerance classes;

(2) calculation of the index value based on all taxa of which more than one individual was found, using Table 2;

(3) determination of water quality class by means of Table 3.

Sampling macroinvertebrates and calculating the $\mathrm{BBI}$ is a rigorous task and should be performed with the highest possible care and precision. Along with the calculation method, many other sources of variability exist, such as seasonality (e.g. Hughes, 1978; Furse et al., 1984; Rosillon, 1989; Linke et al., 1999; Humphrey et al., 2000; Reece et al., 2001), operator (e.g. Humphrey et al., 2000) and sampling variation (e.g. Clarke, 2000; Clarke et al., 2002). Due to all these sources of variability, it is difficult to attain a high precision for the BBI. Nevertheless, these other sources of errors are an additional incentive for using a calculation method that is as rigorous as possible.

\section{Conclusion}

Lack of consensus on how to deal with taxonomic modifications and invasions of exotic species may lead to inconsistencies in biotic index calculation. This problem could be overcome by using a semifixed taxa list. A semi-fixed list of macroinvertebrate taxa including a tolerance class for each taxon is proposed in order to avoid inconsistencies in the calculation procedure of the BBI. This list is based on the taxa identification sensu De Pauw \& Vannevel (1991) with the addition of the Polychaeta family Ampharetidae, the Mollusca genus Corbicula and the Crustacea family Janiridae. It is hoped for that this list may lead to a harmonisation of the BBI calculation practice so that the BBI values can still be compared unambiguously in the future.

\section{Acknowledgements}

The authors wish to thank the VMM, in particular S. De Smedt, A. De Winter, J. Mertens and T. Warmoes for stimulating discussions on the subject and for providing useful sampling data, and Dr. B. Goddeeris of the Royal Belgian Institute of Natural Sciences and an anonymous reviewer for their valuable comments.

\section{References}

Adriaenssens, V., F. Simons, L. T. H. Nguyen, B. Goddeeris, P. L. M. Goethals \& N. De Pauw, 2004. Potential of bioindication of chironomid communities for assessment of running water quality in Flanders (Belgium). Belgian Journal of Zoology 134: 15-24.

Bervoets, L ., B. Bruylants, P. Marquet, A. Vandelannoote \& R. Verheyen, 1989. A proposal for modification of the Belgian Biotic Index method. Hydrobiologia 179: 223-228.

Bij de Vaate, A., K. Jazdzewski, H. A. M. Ketelaars, S. Gollasch \& G. Van der Velde, 2002. Geographical patterns in range extension of Ponto-Caspian macroinvertebrate species in Europe. Canadian Journal of Fisheries and Aquatic Sciences 59: 1159-1174.

Bowman, M. F. \& R. C. Bailey, 1997. Does taxonomic resolution affect the multivariate description of the structure of freshwater benthic macroinvertebrate communities? Canadian Journal of Fisheries and Aquatic Sciences 54: 18021807.

Cairns, J. Jr. \& J. R. Bidwell, 1996. Discontinuities in technological and natural systems caused by exotic species. Biodiversity and Conservation 5: 1085-1094.

Clarke, R. T., 2000. Uncertainty in estimates of biological quality based on RIVPACS. In Wright, J. F., D. W. Sutcliffe \& M. T. Furse (eds), Assessing the Biological Quality of Fresh Waters: RIVPACS and Other Techniques. Freshwater Biological Association, Ambleside, Cumbria, UK: 39-54.

Clarke, R. T., M. T. Furse, R. J. M. Gunn, J. M. Winder \& J. F. Wright, 2002. Sampling variation in macroinvertebrate data and implications for river quality indices. Freshwater Biology 47: 1735-1751. 
De Pauw, N. \& G. Hawkes, 1993. Biological monitoring of river water quality. In Walley, W. J. \& S. Judd (eds), River Water Quality Monitoring and Control. Aston University, Birmingham, UK: 87-111.

De Pauw, N. \& S. Heylen, 2001. Biotic index for sediment quality assessment of watercourses in Flanders, Belgium. Aquatic Ecology 35: 121-133.

De Pauw, N. \& G. Vanhooren, 1983. Method for biological quality assessment of watercourses in Belgium. Hydrobiologia 100: 153-168.

De Pauw, N. \& R. Vannevel (eds), 1991. Macroinvertebrates and Water Quality (in Dutch). Stichting Leefmilieu, Antwerp, Belgium, $316 \mathrm{pp}$.

DIN, 1990. Biological-Ecological Analysis of Water (group M). Determination of the Saprobic Index (M 2). DIN 38 410, Part 2. Beuth Verlag GmbH, Berlin, Germany.

Dolédec, S., J. M. Olivier \& B. Statzner, 2000. Accurate description of the abundance of taxa and their biological traits in stream invertebrate communities: effects of taxonomic and spatial resolution. Archiv für Hydrobiologie 148: 25-43.

Ellis, D., 1985. Taxonomic sufficiency in pollution assessment. Marine Pollution Bulletin 16: 459.

EU, 2000. Directive 2000/60/EC of the European Parliament and of the Council of 23 October 2000 establishing a framework for Community action in the field of water policy. Official Journal of the European Communities L 327 : 172.

Furse, M. T., D. Moss, J . F. Wright \& D. Armitage, 1984. The influence of seasonal and taxonomic factors on the ordination and classification of running-water sites in Great Britain and on the prediction of their macro-invertebrate communities. Freshwater Biology 14: 257-280.

Gayraud, S., B. Statzner, P. Bady, A. Haybach, F. Schöll, P. Usseglio-Polatera \& M. Bacchi, 2003. Invertebrate traits for the biomonitoring of large European rivers: an initial assessment of alternative metrics. Freshwater Biology 48: 2045-2064.

Ghetti, P. F., 1997. Manuale di applicazione Indice Biotico Esteso (I.B.E.). I macroinvertebrati nel controllo della qualità degli ambienti di aque correnti. Provincia Autonoma di Trento, Agenzia provinciale per la protezione degli ambienti, $222 \mathrm{pp}$.

Guérold, F., 2000. Influence of taxonomic determination level on several community indices. Water Research 34: 487-492.

Hughes, B. D., 1978. The influence of factors other than pollution on the value of Shannon's diversity index for benthic macro-invertebrates in streams. Water Research 12: 359-364.

Humphrey, C. L., A. W. Storey \& L. Thurtell, 2000. AUSRIVAS: operator sample processing errors and temporal variability - implications for model sensitivity. In Wright, J. F., D. W. Sutcliffe \& M. T. Furse (eds), Assessing the Biological Quality of Fresh Waters: RIVPACS and Other Techniques. Freshwater Biological Association, Ambleside, Cumbria, UK: 143-163.

IBN, 1984. Biological Quality of Watercourses. Determination of the Biotic Index Based on Aquatic Macroinvertebrates, NBN T92-402 (in Dutch and French). Belgian Institute for Normalisation, Brussels, Belgium, 11 pp.
Karr, J. R. \& E. W. Chu, 1999. Restoring Life in Running Waters: Better Biological Monitoring. Island Press, Washington, DC, USA, $206 \mathrm{pp}$.

King, R. S. \& C. J. Richardson, 2002. Evaluating subsampling approaches and macroinvertebrate taxonomic resolution for wetland bioassessment. Journal of the North American Benthological Society 21: 150-171.

Lenat, D. R. \& V. H. Resh, 2001. Taxonomy and stream ecology - the benefits of genus-and species-level identifications. Journal of the North American Benthological Society 20: $287-298$

Linke, S., R. C. Bailey \& J. Schwindt, 1999. Temporal variability of stream bioassessments using benthic macroinvertebrates. Freshwater Biology 42: 575-584.

Lodge, D. M., 1993. Biological invasions - lessons for ecology. Trends in Ecology \& Evolution 8: 133-137.

Mack, R. N., D. Simberloff, W. M. Lonsdale, H. Evans, M Clout \& F. A. Bazzaz, 2000. Biotic invasions: causes, epidemiology, global consequences, and control. Ecological Applications 10: 689-710.

Nguyen, L . T. H. \& N. De Pauw, 2002. The invasive Corbicula species (Bivalvia, Corbiculidae) and the sediment quality in Flanders, Belgium. Belgian Journal of Zoology 132: 4148 .

Olsgard, F., P. J. Somerfield \& M. R. Carr, 1998. Relationships between taxonomic resolution, macrobenthic community patterns and disturbance. Marine Ecology Progress Series 172: $25-36$.

Reece, P. F., T. B. Reynoldson, J. S. Richardson \& D. M. Rosenberg, 2001. Implications of seasonal variation for biomonitoring with predictive models in the Fraser River catchment, British Columbia. Canadian Journal of Fisheries and Aquatic Sciences 58: 1411-1418.

Resh, V. H. \& E. P. McElravy, 1993. Contemporary quantitative approaches to biomonitoring using benthic macroinvertebrates. In Rosenberg, D. M. \& V. H. Resh (eds), Freshwater Biomonitoring and Benthic Macroinvertebrates. Chapman \& Hall, New York, USA: 159-194.

Roach, A. C., A. R. Jones \& A. Murray, 2001. Using benthic recruitment to assess the significance of contaminated sediments: the influence of taxonomic resolution. Environmental Pollution 112: 131-143.

Rosillon, D., 1989. The influence of abiotic factors and densitydependent mechanisms on between-year variations in a stream invertebrate community. Hydrobiologia 179: 25-38.

Schmidt-Kloiber, A. \& R. C. Nijboer, 2004. The effect of taxonomic resolution on the assessment of ecological water quality classes. Hydrobiologia 516: 269-283.

Stubauer, I. \& O. Moog, 2000. Taxonomic sufficiency versus need for information - comments based on Austrian experience in biological water quality monitoring. Verhandlungen der Internationale Vereinigung für Theoretische und Angewandte Limnologie 27: 2562-2566.

Torchin, M. E., K. D. Lafferty, A. P. Dobson, V. J. McKenzie \& A. M. Kuris, 2003. Introduced species and their missing parasites. Nature 421: 628-630.

Tuffery, G. \& J. Verneaux, 1968. Méthode de détermination de la qualité biologique des eaux courantes. Exploitation codifiée des inventaires de la faune du fond. Ministère de l' 
Agriculture (France), Centre National d'Etudes techniques et de recherches technologiques pour l'agriculture, les forêts et l'équipement rural 'C.E.R.A.F.E.R.', Section Pêche et Pisciculture, $23 \mathrm{pp}$.

Usseglio-Polatera, P. \& J. N. Beisel, 2003. International biomonitoring of the Meuse River: spatio-temporal analysis of benthic communities (1998-2001). Final report (in French). LBFE, Equipe de Démoécologie, Université de Metz, France, 107 pp. + appendices.

Vanden Bossche, J. -P., F. Chérot, E. Delooz, F. Grisez \& G. Josens, 2001. First record of the Pontocaspian invader Hypania invalida (Grube, 1860) (Polychaeta: Ampharetidae) in the river Meuse (Belgium). Belgian Journal of Z oology 131: 183-185.

Vanhooren, G., A. Ovaere, H. De Schutter \& C. Boelen, 1982. Coded list of aquatic macroinvertebrates (in Dutch and French). Instituut voor Hygiene en Epidemiologie, Brussels, Belgium, 58 pp. + appendix.
Van Den Brink, F. W. B., G. Van Der Velde \& A. Bij de Vaate, 1991. Amphipod invasion on the Rhine. Nature 352: 576.

Verdonschot, P. F. M., 2000. Integrated ecological assessment methods as a basis for sustainable catchment management. Hydrobiologia 422/423: 389-412.

Warwick, R. M., 1988. The level of taxonomic discrimination required to detect pollution effects on marine benthic communities. Marine Pollution Bulletin 19: 259-268.

Williams, P. H. \& K. J. Gaston, 1994. Measuring more of biodiversity: can higher-taxon richness predict wholesale species richness? Biological Conservation 67: 211217.

Woodiwiss, F. S., 1964. The biological system of stream classification used by the Trent River Board. Chemistry and Industry 14: 443-447.

Woodiwiss, F. S., 1980. Biological Monitoring of Surface Water Quality. Summary Report. Commission of the European Communities, 45 pp. 